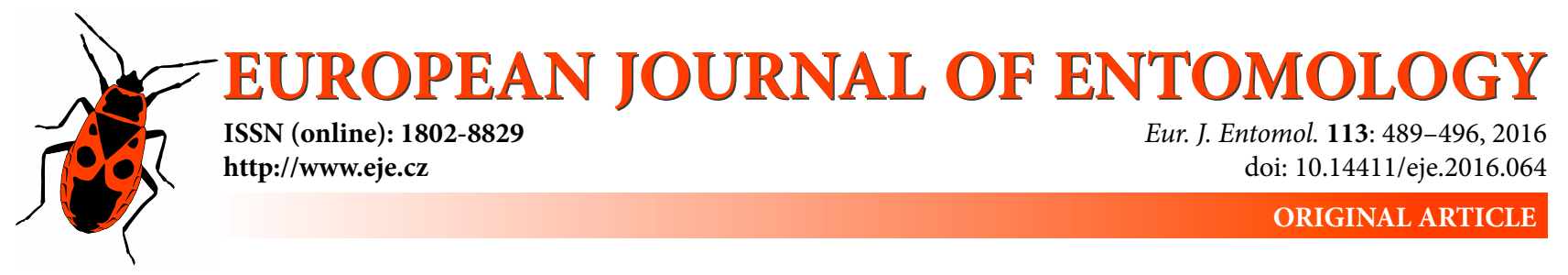

\title{
Seasonal polyphenism in Eristalis pertinax (Diptera: Syrphidae)
}

\author{
Lukasz E. MielCZareK ${ }^{1}$, Andrzej OleKSA ${ }^{2}$, Katarzyna MEYZA² and Adam TOFILSKI ${ }^{1, *}$ \\ ${ }^{1}$ Department of Pomology and Apiculture, Agricultural University, 29 Listopada 54, 31-425 Krakow, Poland; \\ e-mails: lukasz@insects.pl, rotofils@cyf-kr.edu.pl \\ ${ }^{2}$ Department of Genetics, Kazimierz Wielki University, Chodkiewicza 30, 85-064 Bydgoszcz, Poland; \\ e-mails: olek@ukw.edu.pl, kasiakow@ukw.edu.pl
}

Key words. Diptera, Syrphidae, Eristalis pertinax, seasonal polyphenism, wing venation, allometry

\begin{abstract}
Eristalis pertinax varies seasonally, with the spring morph more hairy than the summer morph. We measured the size and the venation of the wings of the seasonal morphs. Wings of the spring morph were significantly larger than those of the summer morph and those of females were larger than those of males. There were also significant differences between the morphs in wing venation and their allometric relationship. The differences between sexes were larger than differences between seasonal morphs. The allometry can account for the sexual dimorphism but not seasonal dimorphism. The differences between seasonal morphs in wing shape were relatively large with very few intermediate individuals. The differences were comparable to those between two related species of Syrphidae. Genetic analyses based on markers in nuclear and mitochondrial genomes unequivocally revealed that spring and summer morphs of $E$. pertinax form a single population and should not be regarded as separate taxa. Thus seasonal variability in this species is a rare example of polyphenism in Diptera.
\end{abstract}

\section{INTRODUCTION}

Most organisms are phenotypically plastic with the same genotype producing different phenotypes in different environments. When there are two or more distinct categories of a phenotype it is often referred to as polyphenism (Nijhout, 2003). In particular, seasonal polyphenism occurs when different phenotypes (seasonal forms or morphs) occur at different times of a year. Seasonal polyphenism is particularly well studied in butterflies for which there are many examples of markedly different seasonal morphs (Shapiro, 1976).

In Diptera seasonal variability is mainly in terms of body colour, which is environmentally induced by the temperature experienced during the pupal stage (Dušek \& Láska, 1974; Heal, 1981, 1989; Holloway, 1993; Ottenheim et al., 1996). Darker adults emerge more often in cool springs than warm summers in Syrphidae, for example in, Eristalis tenax (Heal, 1982, 1989), E. arbustorum (Ottenheim \& Holloway, 1994; Ottenheim et al., 1996), Episyrphus balteatus, Eupeodes corollae, E. latifasciatus and E. luniger (Holloway et al., 1997, Marriott \& Holloway, 1998) and Piophilidae (Martín-Vega \& Baz, 2011). This seasonal change is probably related to thermoregulation because dark forms in spring absorb solar radiation better than pale summer forms (Heal, 1982). However, in Eristalis intri- caria the response to temperature differs with darker individuals developing at higher temperatures (Heal, 1989).

Temperature during larval development can affect the size of various body parts in E. arbustorum (Ottenheim et al., 1998; Ottenheim \& Volmer, 1999) and Drosophila simulans (Debat et al., 2003). A particularly interesting form of seasonal variability occurs in Eristalis pertinax (Scopoli, 1763) in which there are two distinct morphs. In central Europe a spring morph occurs from March to May and summer morph from June to November. There are many differences between the two morphs (Bičík et al., 1996) including: hair length, dusting and position of sensory pit on antennae. In general spring specimens are much more hairy and the hairs longer than in summer individuals. The spring morph is frequently recorded in Scandinavia and rarely in Central Europe (Bičík et al., 1996), whereas the summer morph is abundant in both regions.

The spring morph of E. pertinax was first described as a distinct species, Syrphus flavitarsis Malm, 1860, and later listed as junior synonym of $E$. pertinax by Lundbeck (1916) and Hippa et al. (2001). Recently Bič́k and colleagues (1996) compared the seasonal morphs of E. pertinax and found differences in many body parts but not in male genitalia. They conclude that these morphs belong to one species and suggest that a breeding experiment should

\footnotetext{
* Corresponding author; e-mail: rotofils@cyf-kr.edu.pl.
} 


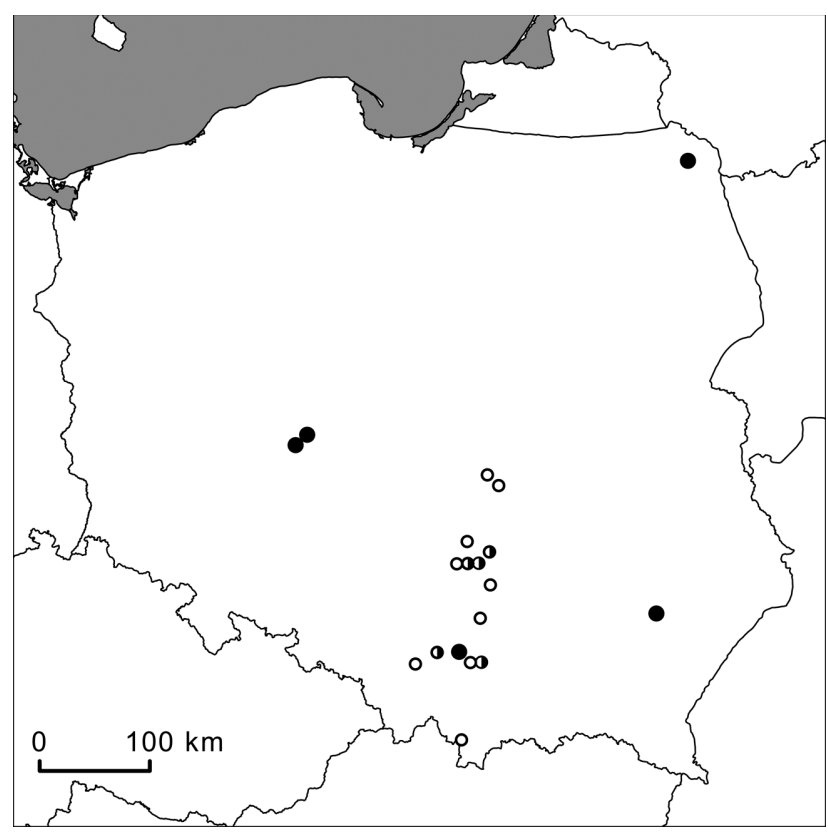

Fig. 1. Map of Poland showing the locations at which samples of the spring morph (empty circles), summer morph (filled circles) and both morphs (half-filled circles) of Eristalis pertinax were collected. One location is missing on this map: Milton Keynes in Great Britain, at which the spring morph was collected.

be done to confirm this (Bičík et al., 1996), which as far as we know has not been done. Therefore, there is no strong evidence if the spring morph is a distinct species or not.

E. pertinax is a relatively widespread species reported throughout most of Europe and Turkey. It prefers forests, especially along rivers, but also occurs in farmland and gardens. E. pertinax is one of the most important pollinators among hoverflies, it regularly visits 182 species of flowering plants (Tóth, 2011). Mark-recapture experiments have revealed that summer adults of E. pertinax are highly mobile and likely to move away from where they emerged. Maximum adult longevity is 17 days and average longevity about 4 days (Holloway \& McCaffery, 1990). Males, like those of many other hoverflies, spend a lot time hovering one to a few meters above the ground (Speight, 2012) or sit on flowers. Females are more often found around the edges of damp woodland, which are their oviposition sites (Holloway \& McCaffery, 1990). It is a relatively large species with a wing length of $8.25-12.75 \mathrm{~mm}$ (Stubbs \& Falk, 2002). In appearance it is a bee mimic and differs from other similar species in having yellow middle and front tarsi. It is a very common species, which occurs from early spring to late autumn. First adults are usually observed in Central Europe in March or at the beginning of April, peaking in the first half of May and beginning of August (Tóth, 2011) and adults are still flying even in November when they are very abundant on ivy flowers (Ball \& Morris, 2000; Tóth, 2011; Stubbs \& Falk, 2002; Mielczarek, 2014). There are no records of adults overwintering.

The main aim of this study was to describe the wing shapes and record the size of the two seasonal morphs of E. pertinax. The molecular analysis was done to check if the two morphs belong to one or two species.

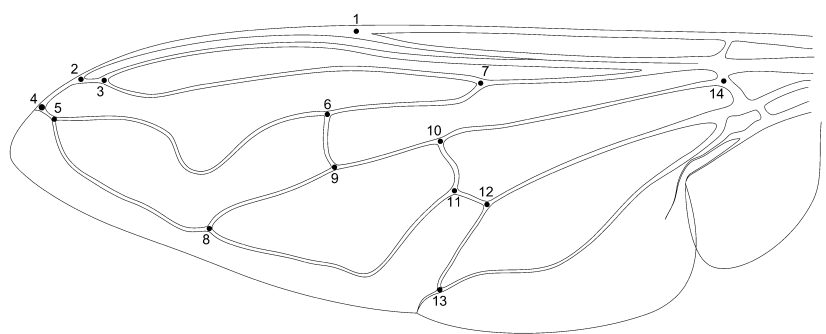

Fig. 2. Schematic diagram of the wing of Eristalis pertinax. Black dots and numbers indicate landmarks used for the wing measurements.

\section{METHODS}

In total 285 specimens of Eristalis pertinax were used in the analysis. Individuals were segregated into two morphs based on the features recorded in Bičík et al. (1996). There were 63 individuals of the spring morph ( 31 females and 32 males) and 222 of the summer morph (158 females and 64 males). Almost all these specimens were collected in lowland areas in Poland (Fig. 1). The spring morph was collected between 3rd April and 29th May. The summer morph was collected between 26th May and 14th October. Wing images were obtained using a CMOS camera (UCMOS09000KPB, ToupTek Photonics) equipped with a $25 \mathrm{~mm}$ lens (FL-CC2514-2M, Ricoh). Fourteen landmarks were designated manually on wing images (Fig. 2) using DrawWing software (Tofilski, 2004). Both left and right wings were measured and the mean value of the two measurements was used in the statistical analysis.

The coordinates of the landmarks were aligned using a generalized orthogonal least-squares procedure (Rohlf \& Slice, 1990). Centroid size was calculated by taking the square root of the sum of squared distances between each landmark and the centroid of each wing. The centroid size was used as a measure of wing size and was compared between sexes and morphs using factorial analysis of variance (ANOVA) in Statistica (StatSoft Inc, 2014). Unless specified otherwise, this software package was used in all other statistical analysis. Wing shape was described using partial warp scores obtained using tpsRelw (1.54 v.) software (Rohlf, 2010) and was analyzed using multiple analysis of covariance (MANCOVA) with wing size as a covariate. This allowed allometry to be taken into account. Identification of morphs and sexes was based on the canonical variate analysis (CVA) of wing shape and size. The identification was validated using the leave-one-out method (jackknife) in PAST 3.11 software (Hammer et al., 2001).

\section{DNA samples and extraction}

Thirty one individuals of the summer morph and 19 of the spring morph, collected from six sites in southern Poland, in the area between Spała and Kraków (meridional extent of $170 \mathrm{~km}$ ), were used in the molecular analyses. Genomic DNA was extracted from insect thoraxes using the Insect Easy DNA Kit (EZNA) (Omega Bio-Tek, Norcross, GA, USA) following the manufacturer's protocol.

\section{Cytochrome c oxidase I (COI) sequences}

To verify the putative taxa, a sequence analysis of the COI gene (cytochrome c oxidase subunit I) was used. This sequence is the most commonly used marker in animal barcoding, including studies of phylogeny in Syrphidae (Locke \& Skevington, 2013). In this study, a 874 bp long fragment of COI was amplified using universal primers C1-J-2183 alias "Jerry" (5'-CCACATTTATTTTGATTTTTTGG-3') and TL-2N-3014 alias "Pat" (5'-TCCAATGCACTAATCTGCCATATTA-3') from Simons et al. (1994). 
For sequence analysis, 12 individuals of the summer morph and 12 of the spring morph were randomly selected. COI amplicons were recovered from all the individuals studied, however, four samples (one of the summer morph and three of the spring morph) were discarded due to short read length and low read quality, thus leaving 20 samples for further examination (11 of the summer morph and 9 of the spring morph). In these samples, the whole COI fragment of $874 \mathrm{bp}$ was recovered. The sequences studied were amplified in $20 \mu \mathrm{l}$ reactions consisting of $10 \mu \mathrm{l} 1 \times$ Qiagen Master Mix (Qiagen Taq PCR Master Mix Kit; Qiagen, Hilden, Germany), $30 \mathrm{ng}$ of genomic DNA template, $0.375 \mu \mathrm{M}$ of each primer (one forward and one reverse), $0.5 \mathrm{mg} / \mathrm{ml} \mathrm{BSA} \mathrm{and}$ $3 \mu \mathrm{L}$ of deionised water. The PCR program for COI started with $95^{\circ} \mathrm{C}$ for $5 \mathrm{~min}$, followed by 32 cycles of $94^{\circ} \mathrm{C}$ for $1 \mathrm{~min}, 50^{\circ} \mathrm{C}$ for $30 \mathrm{~s}$ and $72^{\circ} \mathrm{C}$ for $1 \mathrm{~min}$. The final elongation step at $72^{\circ} \mathrm{C}$ lasted for $7 \mathrm{~min}$. The PCR reactions were done using a PTC200 thermal cycler (BioRad, Hercules, CA, USA).

PCR products were checked on a $1.5 \%$ agarose gel stained with ethidium bromide. Because in addition to the clear bands representing the main products there were some vague bands that were less than $10 \%$ of their intensity, the appropriate bands were excised from the gel and purified using GeneMatrix Agarose-Out DNA Purification Kit (Eur, Gdansk, Poland) before sequencing at the Institute of Biochemistry and Biophysics, Polish Academy of Sciences (Warsaw, Poland). The procedure was done in both directions using the above primers.

Reads from each sample were manually checked and assembled into a consensus using BioEdit (Hall, 1999). The sequences were aligned using ClustalW ver. 1.83 (Larkin et al., 2007) with default settings. A neighbour-joining phylogenetic tree of sequences was reconstructed using the Jukes-Cantor model and 10,000 bootstrap replicates using MEGA version 6.0 software (Tamura et al., 2013). The best nucleotide substitution model was selected using the jModelTest 2.1.10 program (Darriba et al., 2012). For the phylogenetic analysis, we used Eristalis tenax as an out-group (Acc. no. EU431482.1 and KC763485.1). Due to incomplete overlap between our sequences and the $E$. tenax sequence, all positions containing missing data were eliminated, leaving a total of 809 positions in the final dataset. Newly obtained unique sequences were submitted to GenBank under following accession numbers: KX055518, KX055519 and KX055520.

\section{Amplified fragment length polymorphism (AFLP) analysis}

To verify the conclusions drawn from analysis of a single mtDNA sequence, whole-genomic AFLP markers were also used. The AFLP analysis generally followed the original protocol used by Vos et al. (1995). Restriction-ligation reactions were carried out in a total volume of $10 \mu \mathrm{l}$. A single reaction contained $10 \mathrm{ng}$ of genomic DNA, $5 \mathrm{U}$ EcoRI and $5 \mathrm{U}$ TruI (MseI isoschizomer), 1.5 U T4 DNA Ligase, $1 \times$ T4 DNA Ligase Buffer (Thermo Fisher Scientific, Waltham, MA, USA), $0.05 \%$ BSA, $50 \mathrm{mM} \mathrm{NaCl}, 0.5$ $\mathrm{pmol} / \mu \mathrm{l}$ E-Adaptor and $5 \mathrm{pmol} / \mu \mathrm{l} \mathrm{M}$-Adaptor. Reactions were carried out at room temperature overnight and then diluted $5 \times$ with $\mathrm{H}_{2} \mathrm{O}$ in order to obtain PCR matrices (pre-matrix DNA) for pre-selective amplification.

Pre-selective amplifications were carried out in a $10 \mu \mathrm{l}$ total volume. A pre-selective PCR mixture contained $2 \mu$ pre-matrix DNA, $1 \times$ Qiagen Master Mix, $0.5 \mu \mathrm{M}$ E-primer $(\mathrm{E}+\mathrm{A})$ and 0.5 $\mu \mathrm{M}$ M-primer $(\mathrm{M}+\mathrm{C})$. Amplification was carried out using the following program: $72^{\circ} \mathrm{C}$ for $2 \mathrm{~min}, 20$ cycles of $94^{\circ} \mathrm{C}$ for $20 \mathrm{~s}$, $56^{\circ} \mathrm{C}$ for $30 \mathrm{~s}$ and $72^{\circ} \mathrm{C}$ for $2 \mathrm{~min}$, and finally $60^{\circ} \mathrm{C}$ for $30 \mathrm{~min}$. A product of pre-selective PCR was diluted 20 times in order to obtain a PCR matrix for selective amplification (sel-matrix DNA).

Selective amplifications were carried out using two combinations of primers (in $10 \mu \mathrm{l}$ total volumes, consisting of $3 \mu \mathrm{l}$ sel- matrix DNA, 1× Qiagen Master Mix, 0.5 $\mu \mathrm{M}$ FAM-labelled E-primer $(\mathrm{E}+\mathrm{ACA})$ and $0.5 \mu \mathrm{M} \mathrm{M}$-primer $(\mathrm{M}+\mathrm{CAC}$ or $\mathrm{M}+$ CAG). PCR reaction was carried out at $94^{\circ} \mathrm{C}$ for $2 \mathrm{~min}, 10$ cycles of $94^{\circ} \mathrm{C}$ for $20 \mathrm{~s}, 66^{\circ} \mathrm{C}\left(-1^{\circ}\right.$ per cycle) for $30 \mathrm{~s}$ and $72^{\circ} \mathrm{C}$ for 2 min, 20 cycles of $94^{\circ} \mathrm{C}$ for $30 \mathrm{~s}, 56^{\circ} \mathrm{C}$ for $30 \mathrm{~s}$ and $60^{\circ} \mathrm{C}$ for 30 $\mathrm{min}$. Both pre-selective and selective amplifications were carried out using a PTC200 thermocycler.

The products of selective amplifications were sized using an automated capillary sequencer ABI3130XL (Appllied Biosystems, Foster City, CA, USA). AFLP fingerprint chromatograms were analyzed in a GeneMarker ver. 2.6.3 (SoftGenetics, State College, PA, USA) using normalized calling of all fragments within the range $60-500 \mathrm{bp}$. In the analysis, the following settings were applied: baseline subtraction, no stutter peak and plus-A filtering, and unconfidence at the right site $<30$. Marker bins were automatically created based on default settings. Raw peak intensity data for all bins were subsequently transformed into a binary data matrix with AFLPScore R-script (Whitlock et al., 2008), using the following settings: locus selection threshold equal to $200 \%$ of the grand mean normalised peak height across loci and phenotype-calling threshold equal to $25 \%$ of peak height in locus. Such a restrictive locus selection threshold was adopted in order to remove loci containing lower peaks, which are less reproducible and more difficult to score. However, other settings were also tested and despite their effect on the resulting number of loci, they had no substantial influence on estimated genetic statistics and ultimate conclusions (results not shown). Finally, resulting binary AFLP data matrix was examined for non-polymorphic loci, which were removed before further analyses.

Characteristics of genetic diversity were calculated using AFLP-SURV v1.0 (Vekemans et al., 2002). Expected heterozygosity $\left(H_{e}\right)$ was estimated for all loci using a Bayesian approach with non-uniform prior distribution of allele frequencies and assuming Hardy-Weinberg genotypic proportions. Significance of pairwise $F_{S T}$ between spring and summer samples was tested by comparing the observed $F_{S T}$ value with a distribution of $F_{S T}$ values based on 10,000 random permutations of individuals among assumed populations.

To determine whether the two morphs were genetically distinct, the AFLP data were analyzed to check for any subdivisions within the material studied and if they coincided with the division into two morphs. First, principal component analysis (PCA) was performed using the adegenet $\mathrm{R}$ package (Jombart, 2008). PCA can summarize the genetic variability without assuming a HardyWeinberg equilibrium or linkage disequilibrium, which makes PCA an especially valuable method when no information exists about the genetics of the organism studied. Next, population structure was explored using a model-based clustering method implemented in the program STRUCTURE ver. 2.3.4 (Pritchard et al., 2000; Falush et al., 2007). In contrast to PCA, STRUCTURE relies on strong assumptions about the genetic processes within the system studied (i.e. Hardy-Weinberg equilibrium within populations, no linkage between loci).

The membership of each individual studied was tested for a range of genetic clusters from $K=2$ to 5 using an admixture model and without prior information on their origin. Five independent runs were assessed for each fixed $K$ and each run consisted of 500,000 burn-in periods and 1,000,000 iterations.

\section{RESULTS}

Wing size differed both between seasonal morphs and sexes. The spring morph was larger than the summer $\operatorname{morph}\left(\mathrm{F}_{(1,281)}=13.65, \mathrm{p}=0.0002\right)$ and females were larger than males in both morphs $\left(\mathrm{F}_{(1,281)}=94.68, \mathrm{p}<0.0001\right)$. 


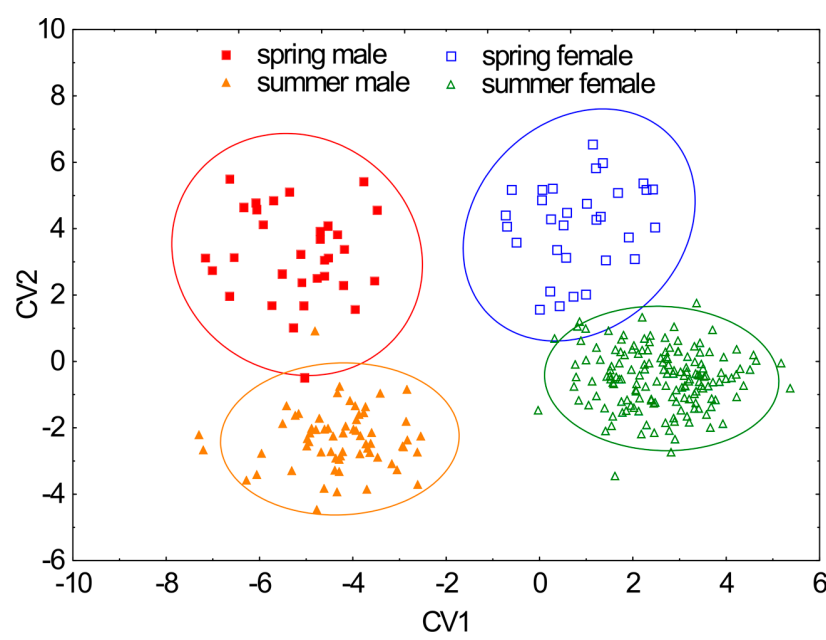

Fig. 3. Discrimination of sexes and seasonal morphs of Eristalis pertinax based on the first two canonical variates.

Interaction between those two factors was not significant $\left(\mathrm{F}_{(1,281)}=1.86, \mathrm{p}=0.1735\right)$.

MANCOVA for both morphs and sexes revealed presence of wing shape allometry (change in wing shape with size; Table 1A effect of size). There were significant differences in wing shape between seasonal morphs (Table 1A effect of morph) but not between sexes (Table 1A effect of sex). Moreover there was a complex pattern of interactions (Table 1A).

MANCOVA calculated for each of the morphs separately confirmed that there was an allometric response (Table $1 \mathrm{BC}$ effect of size), which did not differ significantly between sexes (Table 1BC interaction between size and sex). There was no significant effect of sex (Table 1BC), which indicates that differences in wing shape between males and females, within each morph, can be explained by allometry alone.

Table 1. MANCOVA of wing shape with wing size as a covariate for both morphs and sexes A, spring morph $\mathrm{B}$, summer morph $\mathrm{C}$ males $\mathrm{D}$ and females $\mathrm{E}$.

\begin{tabular}{|c|c|c|c|}
\hline Effect & Wilks $\wedge$ & $F$ & $P$ \\
\hline $\begin{array}{l}\text { A-both morphs and both sexes } \\
\text { Morph } \\
\text { Sex } \\
\text { Size } \\
\text { Morph*sex } \\
\text { Morph*size } \\
\text { Sex*size } \\
\text { Morph*sex*size }\end{array}$ & $\begin{array}{l}0.853 \\
0.876 \\
0.578 \\
0.837 \\
0.875 \\
0.870 \\
0.845\end{array}$ & $\begin{array}{l}1.82 \\
1.50 \\
7.71 \\
2.05 \\
1.51 \\
1.58 \\
1.94 \\
\end{array}$ & $\begin{array}{r}0.0127 \\
0.0685 \\
<0.0001 \\
0.0034 \\
0.0651 \\
0.0457 \\
0.0065\end{array}$ \\
\hline $\begin{array}{l}\text { B - spring morph } \\
\text { Sex } \\
\text { Size } \\
\text { Sexsize }\end{array}$ & $\begin{array}{l}0.490 \\
0.315 \\
0.497 \\
\end{array}$ & $\begin{array}{l}1.56 \\
3.26 \\
1.52 \\
\end{array}$ & $\begin{array}{l}0.1098 \\
0.0007 \\
0.1251\end{array}$ \\
\hline $\begin{array}{l}\text { C-summer morph } \\
\text { Sex } \\
\text { Size } \\
\text { Sex*size }\end{array}$ & $\begin{array}{l}0.870 \\
0.517 \\
0.853 \\
\end{array}$ & $\begin{array}{l}1.22 \\
7.59 \\
1.40 \\
\end{array}$ & $\begin{array}{r}0.2306 \\
<0.0001 \\
0.1113 \\
\end{array}$ \\
\hline $\begin{array}{l}\text { D - males } \\
\text { Morph } \\
\text { Size } \\
\text { Morph*size } \\
\end{array}$ & $\begin{array}{l}0.531 \\
0.294 \\
0.560 \\
\end{array}$ & $\begin{array}{l}2.54 \\
6.91 \\
2.26 \\
\end{array}$ & $\begin{array}{r}0.0014 \\
<0.0001 \\
0.0046 \\
\end{array}$ \\
\hline $\begin{array}{l}\text { E-females } \\
\text { Morph } \\
\text { Size } \\
\text { Morph*size }\end{array}$ & $\begin{array}{l}0.764 \\
0.628 \\
0.776\end{array}$ & $\begin{array}{l}2.09 \\
4.00 \\
1.95\end{array}$ & $\begin{array}{r}0.0039 \\
<0.0001 \\
0.0082\end{array}$ \\
\hline
\end{tabular}
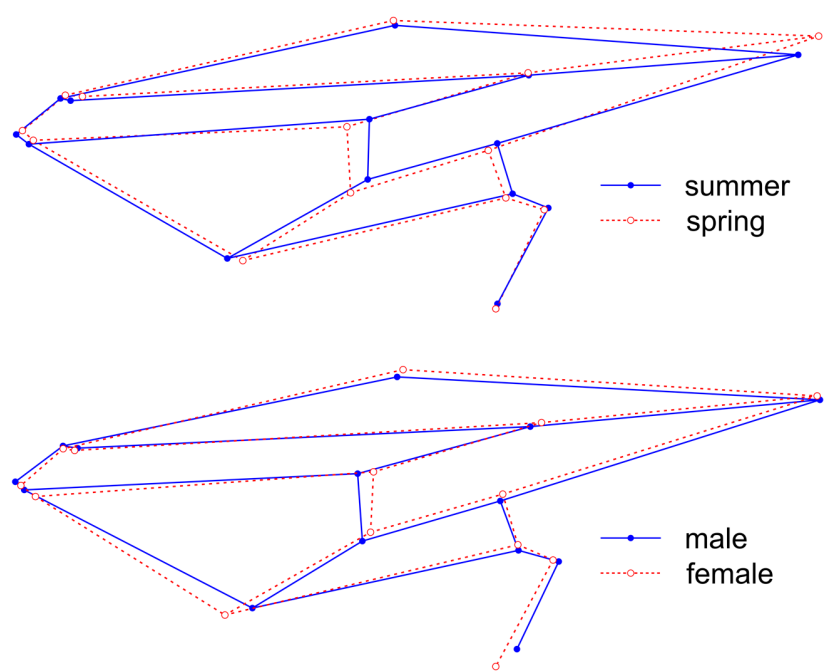

Fig. 4. Differences in wing shape of spring and summer morphs (top graph) and males and females (bottom graph) of Eristalis pertinax. Points on the graphs correspond to the landmarks indicated in Fig. 1. The differences were increased two times in order to make them more visible.

On the other hand MANCOVA calculated for each of the sexes separately showed that allometry (Table 1DE effect of size) differed significantly between morphs (Table 1DE, interaction between size and morph). In both sexes there were also significant differences in wing shape between morphs (Table 1DE effect of morph). This indicates that differences between morphs cannot be explained by allometry.

Canonical variate analysis revealed differences not only between seasonal morphs but also between males and females (Fig. 3). The differences in size between sexes were large enough for allometric effects to clearly separate them. Seasonal morphs differed mainly in the position of r-m cross vein (Fig. 2, vein between landmarks 6 and 9) and landmark 14. Wing of spring morph was longer than that of the summer morph (Fig. 4). Wings of females were wider than those of males (Fig. 4). CVA correctly classified (with leave-one-out cross-validation) $98.25 \%$ of the individuals. The cases of misclassification occurred only within the same sex (Table 2). The wing shape differed more between sexes than between seasonal morphs (Table 3). In pair-wise comparisons all groups differed significantly from each other (Table 3 ).

We did not detect any geographical variation in wing shape. In particular differences in wing shape were neither significant between males of the spring morph from Great Britain and Poland (MANOVA: Wilks $\Lambda=0.162, \mathrm{~F}<$ $0.001, \mathrm{P}=0.97)$ nor between females of the summer morph

Table 2. Classification of seasonal morphs and sexes of Eristalis pertinax.

\begin{tabular}{lcccc}
\hline \multirow{2}{*}{ Group } & \multicolumn{4}{c}{ Classified as } \\
\cline { 2 - 5 } & $\begin{array}{c}\text { spring } \\
\text { female }\end{array}$ & $\begin{array}{c}\text { spring } \\
\text { male }\end{array}$ & $\begin{array}{c}\text { summer } \\
\text { female }\end{array}$ & $\begin{array}{c}\text { summer } \\
\text { male }\end{array}$ \\
\hline Spring female & 29 & 0 & 2 & 0 \\
Spring male & 0 & 31 & 0 & 1 \\
Summer female & 1 & 0 & 157 & 0 \\
Summer male & 0 & 1 & 0 & 63 \\
\hline
\end{tabular}




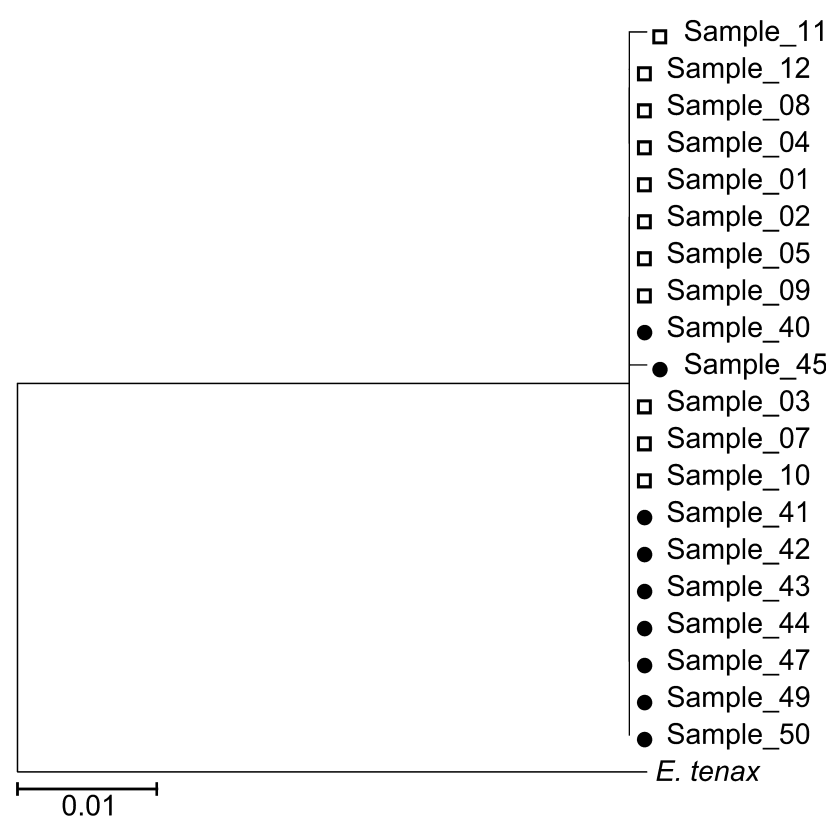

Fig. 5. Relationships between COI sequences, inferred using the Neighbour-joining method. Samples of the summer morph are indicated by white squares and the spring morph by black dots. The tree is drawn to scale, with branch lengths in terms of the number of base substitutions per site (distances were computed using the Jukes-Cantor method). All positions containing gaps and missing data were eliminated. There were a total of 809 positions in the final dataset.

from north and south Poland (MANOVA: Wilks $\Lambda=0.683$, $\mathrm{F}=1.1, \mathrm{P}=0.40)$.

\section{Sequence of the COI gene}

All samples shared the same sequence, except for two variable positions in two samples (transition from A to $G$ in positions 198 and 673, samples 45 and 11, respectively). Pairwise genetic distances between the samples studied ranged from 0.0000 to 0.0012 , while the distance to the out group (E. tenax) was significantly greater and accounted for 0.0891 (in the units of the number of base substitutions per site, Fig. 5). Since there were no differences between the samples investigated or they were too small for an interspecific difference, sequence analysis did not provide any evidence for the existence of two separate species within the E. pertinax complex.

\section{AFLP}

All specimens whose COI gene was successfully sequenced were also successfully genotyped using AFLP markers. Two combinations of primers yielded amplifica-

Table 3. Mahalanobis distances between seasonal morphs and sexes of Eristalis pertinax (top right triangle) and significance of the pairwise differences between the groups (bottom left triangle).

\begin{tabular}{lcccc}
\hline & $\begin{array}{c}\text { Spring } \\
\text { female }\end{array}$ & $\begin{array}{c}\text { Spring } \\
\text { male }\end{array}$ & $\begin{array}{c}\text { Summer } \\
\text { female }\end{array}$ & $\begin{array}{c}\text { Summer } \\
\text { male }\end{array}$ \\
\hline Spring female & - & 6.18 & 5.08 & 7.91 \\
Spring male & $* * *$ & - & 8.24 & 5.78 \\
Summer female & $* * *$ & $* * *$ & - & 6.36 \\
Summer male & $* * *$ & $* * *$ & $* * *$ & - \\
\hline
\end{tabular}

${ }^{* * *} P$ value lower than 0.0001

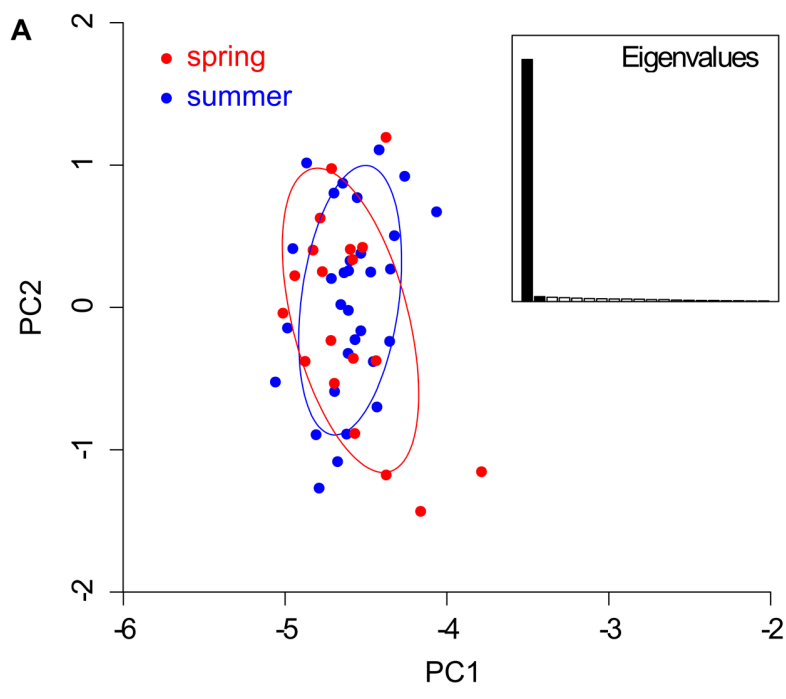

B

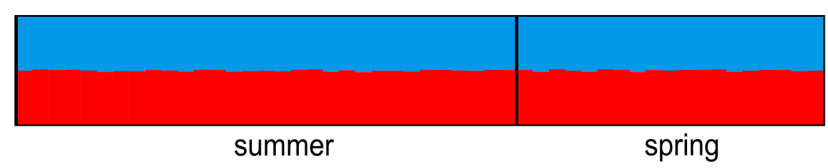

Fig. 6. A - PCA results obtained using the AFLP data. Individuals are plotted according to their coordinates on the first two principal components. Ellipses characterize the dispersion of each morph around its center of gravity (assuming the cloud is a random sample distributed according to a bivariate Gaussian distribution, the probability for an individual to be within the ellipse is 0.9 ). $\mathrm{B}-$ output of program STRUCTURE assuming two populations $(K=2)$. Each individual is represented by a vertical line divided into $\mathrm{K}$ colours indicating genetic membership probabilities.

tion of 360 potential loci (i.e. peaks visible in the electropherogram), 199 from E_ACA $\times$ M_CAC and 161 from E_ACA $\times$ M_CAG. From this number, 325 loci were not included in further analyses either because of the filtering criteria used (see Methods) or lack of polymorphism, which left 35 AFLP loci for further analyses $\left(E \_A C A \times\right.$ M_CAC -21, E_ACA $\times$ M_CAG - 14). Missing data in AFLP loci amounted to $1.6 \%$ and were related to poor amplification of one selective primer combination (E_ACA x M_CAG) in four samples. Expected heterozygosity was slightly lower in the summer than in the spring morph $(0.35 \pm 0.02$ and $0.41 \pm 0.02$, respectively). Pairwise $F_{S T}$ between the two morphs was estimated to be 0.024 , which was not significantly different from zero ( $95 \%$ confidence limits from -0.013 to 0.025 ), indicating that all the samples studied should be regarded as belonging to a single population.

This result was confirmed by the principal component analysis (PCA), which was not able to detect differences between the two groups (Fig. 6A) because ranges in the variation of both morphs strongly overlapped. The first principal component accounted for $21.19 \%$ of the variance, while the remaining principal components accounted for very little variability ( $0.44 \%$ and less) and were not interpretable, indicating that the samples studied were characterized by low variability.

Similar to the PCA, the STRUCTURE analysis was unable to detect any clustering (Fig. 6B). Estimated assignment probabilities revealed no difference between spring 
and summer morphs. For any values of $K$, from 2 to 5 , the probability that an individual belonged to one of the assumed populations was $1 / K$, which strongly indicated that all the individuals studied belonged to a single genetic population.

\section{DISCUSSION}

In this paper we describe the differences in the wing venation of spring and summer morphs of E. pertinax. The seasonal morphs differed in many ways including size, shape of venation and allometry. The differences in wing shape were particularly large with very few intermediate individuals. There are even bigger differences between the seasonal morphs of $E$. pertinax in length of body hairs and antennal morphology (Bičík et al., 1996). These characters are clearly distinct and intermediate forms occur only sporadically (Bičík et al., 1996). Therefore, it is justified to call this form of phenotypic plasticity in E. pertinax polyphenism as defined by Nijhout (2003). There are very few reports of seasonal polyphenism in Diptera. Apart from $E$. pertinax (Bičík et al., 1996), seasonal variation in Syrphidae is also reported in E. arbustorum (Ottenheim et al., 1999), Cheilosia vernalis (Milankov et al., 2002; Ståhls et al., 2008) and C. pagana (Stubbs \& Falk, 2002), in which the spring morphs are larger, brighter and longer haired than the summer forms. The earlier reports of polyphenism in hoverflies are based on observations. Here we provide a quantitative description of wing shape and show that the two seasonal morphs of E. pertinax are distinct. In Diptera seasonal differences in body colour are more frequently recorded (as mentioned in the introduction). The differences between seasons in body colour of Syrphidae are not distinct with many intermediate forms, therefore, they should not be considered to be a polyphenism.

There are two alternative models of the evolution of polyphenism: extreme allometry and developmental reprogramming (Nijhout \& Wheeler, 1996; Tomkins \& Moczek, 2009). It has been demonstrated that extreme allometry can lead to polyphenism in beetles (Tomkins et al., 2005). This is possible when the morphs differ markedly in body size. In our study allometry can account for some of the differences in the wing venation of males and females but not the differences between seasonal morphs. Thus it is assumed that the spring and summer morphs in E. pertinax originate as a result of developmental reprogramming.

The seasonal polyphenism in E. pertinax is probably adaptive and associated with seasonal differences in temperature. Longer and a greater density of hairs can help the spring morph control its temperature, because they maintain a layer of air close to the body surface, trap absorbed heat and increase insulation. Differences in the length of body hairs are recorded for bumblebees, in which species and populations in cooler regions have relatively longer hairs than those in warmer regions (Peat et al., 2005). Another adaptation of the spring morph to lower temperatures may be its larger body size. Large individuals have smaller body surface area to volume ratio and a lower rate of heat loss than small individuals (Stone \& Willmer, 1989). It is also possible that polyphenism is related to mimicry. Most Syrphidae are mimics of wasps and bees (Dittrich et al., 1993) and, therefore, it is possible that the spring morph mimics a different species to the summer morph. Such colour polymorphisms are recorded for Merodon equestris (Conn, 1972) and Volucella bombylans (Gabritschevsky, 1926).

The morphological differences between the different morphs of $E$. pertinax are relatively large and comparable with those between related species of other hoverflies (Ludoški et al., 2008; Francuski et al., 2009a; b; Soszyński et al., 2013; Vujić et al., 2013). In the past, spring and summer morphs of $E$. pertinax were suggested to be possibly different species (Bičík et al., 1996). However, genetic analyses based on markers in nuclear and mitochondrial genomes unequivocally revealed that the spring and summer morphs belong to a single population and should not be regarded as separate taxa. This confirms the designation of $E$. flavitarsis as a junior synonym of $E$. pertinax by Lundbeck (1916). Usually, a value of $1 \%$ or $2 \%$ divergence in the mtDNA barcode is regarded as the threshold for separating intraspecific and interspecific differences (Steinke et al., 2009; Pereira et al., 2013). In our study the divergence between the sequences studied is much smaller ( 0 to $0.1 \%$ ), indicating that the samples studied belong to a single species. It should be noted, however, that barcoding, i.e. using single mitochondrial genes to delineate species (Hebert et al., 2003), has certain limitations. In some cases, low success of barcoding may result from the nonmonophyly of some species at the mitochondrial level (Whitworth et al., 2007). In particular, current or historical episodes of hybridization and gene flow between closely related taxa may obscure the usefulness of barcoding (Williams \& Villet, 2013). Some previous studies recorded that two species have the same COI sequence (Whitworth et al., 2007). Therefore, in our study, whole-genome AFLP markers were employed, which made it possible to dismiss any doubts there were about the utility of the COI barcode. Due to their ease of amplification across taxa, genome-wide coverage and sensitivity to small genetic differences, AFLP markers are recommended as a complementary analysis in cases where mtDNA barcoding reveals unanticipated results, such as a failure to detect presumed taxonomic divisions or the presence of unexpected cryptic taxa (Dasmahapatra et al., 2010).

Although genetic markers unequivocally indicate that the spring and summer morphs belong to the same species, even more convincing evidence could be provided by a breeding experiment (Bičík et al., 1996). Obtaining the spring morph from the summer morph would be definitive evidence of seasonal variation within one species. Such an experiment could also provide information about the number of generations in a season. It is highly likely that individuals of the summer morph are offspring of the spring morph. This is possible because under favourable conditions larval development in E. tenax can be shorter than one month (Hartley, 1961) and the puparial phase in E.pertinax lasts approximately one month (Dussaix, 2013). 
Moreover, there are two peaks of abundance of this species during a year (Reemer et al., 2009). However, it is also possible that there is only one generation per year with the adults emerging at different times of the year (Hartley, 1961).

To conclude, the results presented here confirm that, despite large morphological differences, spring and summer morphs of E. pertinax belong to one species. In this species both allometry and developmental reprogramming shaped the evolution of phenotypic plasticity. Allometry was more important for the evolution of sexual dimorphism and reprogramming more important for evolution of seasonal dimorphism.

ACKNOWLEDGEMENTS. We would like to thank two anonymous reviewers for helpful comments on earlier versions of this paper. E. Sztupecka helped with the laboratory work, P. Żurawlew, R. Celadyn and K. Igielski provided specimens for this study. Molecular analyses were supported by the Polish Ministry of Science and Higher Education through statutory research funds received by the Department of Genetics KWU. This research was supported by the Ministry of Science and Higher Education grant number DS-3500 to LM.

\section{REFERENCES}

Ball S.G. \& Morris R.K.A. 2000: Provisional Atlas of British Hoverflies (Diptera, Syrphidae). Biological Records Centre, Huntington, $167 \mathrm{pp}$.

Bičík V., Nielsen T. \& Holinka J. 1996: On seasonal variation in Eristalis pertinax (Scopoli) and the status of E. flavitarsis (Malm) (Dipt., Syrphidae). - Acta. Univ. Palackianae Olomuc. (Biol.) 34: 7-12.

ConN D.L.T. 1972: The genetics of mimetic colour polymorphism in the large narcissus bulb fly, Merodon equestris Fab. (Diptera: Syrphidae). - Philos. Trans. R. Soc. Lond. (B, Biol. Sci.) 264: 353-402.

Darriba D., Taboada G.L., Doallo R. \& Posada D. 2012: jModelTest 2: more models, new heuristics and parallel computing. — Nat. Methods 9: 772, 4 pp.

Dasmahapatra K.K., Elias M., Hill R.I., Hoffman J.I. \& Mallet J. 2010: Mitochondrial DNA barcoding detects some species that are real, and some that are not. - Mol. Ecol. Resour. 10: 264-273.

Debat V., Béagin M., Legout H. \& David J.R. 2003: Allometric and nonallometric components of Drosophila wing shape respond differently to developmental temperature. - Evolution 57: 2773-2784.

Dittrich W., Gilbert F., Green P., Mcgregor P. \& Grewcock D. 1993: Imperfect mimicry: a pigeon's perspective. - Proc. $R$. Soc. Lond. (B, Biol. Sci.) 251: 195-200.

DušEK J. \& LÁSKA P. 1974: Influence of temperature during pupal development on the colour of syrphid adults (Syrphidae, Diptera). - Folia Fac. Sci. Nat. Univ. Purkynianae Brun. (Biol.) 15: $77-81$.

Dussaix C. 2013: Syrphes de la Sarthe: Ethologie, Ecologie, Répartition et Développement Larvaire (Diptera, Syrphidae). Invertébrés Armoricains, les Cahiers du GRETIA 9, Rennes, $284 \mathrm{pp}$.

Falush D., Stephens M. \& Pritchard J.K. 2007: Inference of population structure using multilocus genotype data: dominant markers and null alleles. - Mol. Ecol. Notes 7: 574-578.

Francuski L., Vujić A., Kovačević A., LudošKi J. \& Milankov V. 2009a: Identification of the species of the Cheilosia variabilis group (Diptera, Syrphidae) from the Balkan Peninsula using wing geometric morphometrics, with the revision of status of C. melanopa redi Vujic, 1996. - Contrib. Zool. 78: 129-140.

Francuski L., LudošKi J., VuJić A. \& Milankov V. 2009b: Wing geometric morphometric inferences on species delimitation and intraspecific divergent units in the Merodon ruficornis group (Diptera, Syrphidae) from the Balkan Peninsula. Zool. Sci. 26: 301-308.

GABRITSCHEVSKY E. 1926: Convergence of coloration between American pilose flies and bumblebees (Bombus). - Biol. Bull. 51: 269-287.

HALL T. 1999: BioEdit: a user-friendly biological sequence alignment editor and analysis program for Windows 95/98/NT. Nucleic Acids Symp. Ser. 41: 95-98.

HAMmer Ø., HARPER D. \& RYAN P. 2001: PAST: Paleontological statistics software package for education and data analysis. Palaeontol. Electron. 4(1): 4, 9 pp.

HaRTLEY J.C. 1961: A taxonomic account of the larvae of some British Syrphidae. - Proc. Zool. Soc. Lond. 136: 505-573.

HeAL J.R. 1981: Colour patterns of Syrphidae. III. Sexual dimorphism in Eristalis arbustorum. - Ecol. Entomol. 6: 119-127.

HeAL J.R. 1982: Colour patterns of Syrphidae: IV. Mimicry and variation in natural populations of Eristalis tenax. - Heredity 49: $95-109$.

Heal J.R. 1989: Variation and seasonal changes in hoverfly species: interactions between temperature, age and genotype. Biol. J. Linn. Soc. 36: 251-269.

Hebert P.D.N., Cywinska A., Ball S.L. \& de WaArd J.R. 2003: Biological identifications through DNA barcodes. - Proc. Biol. Sci. 270: 313-321.

Hippa H., Nielsen T.R. \& van SteEnis J. 2001: The West Palaearctic species of the genus Eristalis Latreille (Diptera, Syrphidae). - Norw. J. Entomol. 48: 289-327.

Holloway G.J. 1993: Phenotypic variation in colour pattern and seasonal plasticity in Eristalis hoverflies (Diptera: Syrphidae). - Ecol. Entomol. 18: 209-217.

Holloway G.J., Marriott C.G. \& Crocker H.J. 1997: Phenotypic plasticity in hoverflies: the relationship between colour pattern and season in Episyrphus balteatus and other Syrphidae. - Ecol. Entomol. 22: 425-432.

Holloway G.J. \& McCaffery A.R. 1990: Habitat utilization and dispersion in Eristalis pertinax (Diptera: Syrphidae). — Entomologist 109: 116-124.

JOMBART T. 2008: Adegenet: A R package for the multivariate analysis of genetic markers. - Bioinformatics 24: 1403-1405.

Larkin M.A., Blackshields G., Brown N.P., Chenna R., McGettigan P.A., McWilliam H., Valentin F., Wallace I.M., Wilm A., LOPEZ R. ET AL. 2007: ClustalW and ClustalX version 2.0. - Bioinformatics 23: 2947-2948.

Locke M.M. \& Skevington J.H. 2013: Revision of Nearctic Dasysyrphus Enderlein (Diptera: Syrphidae). — Zootaxa 3660: $1-80$.

LudošKi J., Francuski L., Vujić A. \& Milankov V. 2008: The Cheilosia canicularis group (Diptera: Syrphidae): species delimitation and evolutionary relationships based on wing geometric morphometrics. - Zootaxa 1825: 40-50.

LundBeck W. 1916: Diptera Danica Part V: Lonchopteridae, Syrphidae. William Wesley, Copenhagen, $603 \mathrm{pp}$.

Marriott C.G. \& Holloway G.J. 1998: Colour pattern plasticity in the hoverfly, Episyrphus balteatus: the critical immature stage and reaction norm on developmental temperature. $-J$. Insect Physiol. 44: 113-119.

Martín-Vega D. \& Baz A. 2011: Variation in the colour of the necrophagous fly, Prochyliza nigrimana (Diptera: Piophilidae): 
A case of seasonal polymorphism. - Eur. J. Entomol. 108 231-234.

MielCZAReK Ł.E. 2014: Flies recorded in Rakowicki Cemetery in Krakow. - Dipteron 30: 43-49.

Milankov V., Stamenković J., Vujić A. \& Šimić S. 2002: Geographic variation of Cheilosia vernalis (Fallen, 1817) (Diptera: Syrphidae). - Acta Zool. Acad. Sci. Hung. 48: 255-267.

Nishout H.F. 2003: Development and evolution of adaptive polyphenisms. - Evol. Dev. 5: 9-18.

NiJhout H.F. \& WheELER D.E. 1996: Growth models of complex allometries in holometabolous insects. - Am. Nat. 148: 40-56.

Otтenheim M.M. \& Holloway G.J. 1994: The effect of diet and light on larval and pupal development of laboratory-reared Eristalis arbustorum (Diptera: Syrphidae). — Neth. J. Zool. 45: 305-314.

Ottenheim M.M. \& Volmer A.D. 1999: Wing length plasticity in Eristalis arbustorum (Diptera: Syrphidae). — Neth. J. Zool. 49: 15-27.

Ottenheim M.M., Volmer A.D. \& Holloway G.J. 1996: The genetics of phenotypic plasticity in adult abdominal colour pattern of Eristalis arbustorum (Diptera: Syrphidae). - Heredity 77: 493-499.

Ottenheim M.M., Henseler A. \& Brakefield P.M. 1998: Geographic variation in plasticity in Eristalis arbustorum. - Biol. J. Linn. Soc. 65: 215-229.

Ottenheim M.M., Wertheim B., Holloway G.J. \& BraKefield P.M. 1999: Survival of colour-polymorphic Eristalis arbustorum hoverflies in semi-field conditions. - Funct. Ecol. 13: $72-77$.

Peat J., Darvill B., Ellis J. \& Goulson D. 2005: Effects of climate on intra- and interspecific size variation in bumble-bees. - Funct. Ecol. 19: 145-151.

Pereira L.H.G., Hanner R., Foresti F. \& Oliveira C. 2013: Can DNA barcoding accurately discriminate megadiverse Neotropical freshwater fish fauna? - BMC Genet. 14: 20, 14 pp.

Pritchard J.K., Stephens M. \& DonNelly P. 2000: Inference of population structure using multilocus genotype data. - Genetics 155: 945-959.

Reemer M., Renema W., van Steenis W., Zeegers T., Barendregt A., Smit J.T., van Veen M., van Steenis J. \& van der LeiJ L. 2009: Hoverflies of the Netherlands (Diptera: Syrphidae). Nederlandse Fauna 8. Nationaal Natuurhistorisch Museum Naturalis, KNNV Uitgeverij, European Invertebrate Survey - Nederland, Leiden, 442 pp. [in Dutch, English summary].

Rohlf F.J. 2010: tpsRelw, version 1.46. Dep. Ecol. Evol., State Univ. N. Y. Stony Brook: Stony Brook, NY. URL: http://ife. bio.sunysb.edu/morph/.

Rohlf F.J. \& Slice D. 1990: Extensions of the Procrustes method for the optimal superimposition of landmarks. - Syst. Zool. 39: 40-59.

ShAPIRo A.M. 1976: Seasonal polyphenism. - Evol. Biol. 9: 259-333.

Simons C., Frati F., Beckenbach A., Crespi B., Liu H. \& Flook P. 1994: Evolution, weighting, and phylogenetic utility of mitochondrial gene sequences and a compilation of conserved polymerase chain reaction primers. - Ann. Entomol. Soc. Am. 87: 651-701.
SoszyŃski B., Mielczarek L.E. \& Tofilski A. 2013: Dasysyrphus neovenustus sp. n. (Diptera: Syrphidae) a new species in the venustus species group. - Pol. J. Entomol. 82: 353-363.

Speight M.C.D. 2012: Species Accounts of European Syrphidae (Diptera). Syrph Net Database Eur. Syrphidae 69, Dublin, 296 pp.

StÅHls G., Vujić A. \& Milankov V. 2008: Cheilosia vernalis (Diptera, Syrphidae) complex: molecular and morphological variability. - Ann. Zool. Fenn. 45: 149-159.

StatSoft INC. 2014: STATISTICA (data analysis software system), version 12. URL: http://www.statsoft.com.

Steinke D., Zemlak T.S. \& Hebert P.D.N. 2009: Barcoding nemo: DNA-based identifications for the ornamental fish trade. - PLoS ONE 4(7): e6300, 5 pp.

Stone G.N. \& WiLlmer P.G. 1989: Warm-up rates and body temperatures in bees: the importance of body size, thermal regime and phylogeny. - J. Exp. Biol. 147: 303-328.

StubBs A.E. \& Falk S.J. 2002: British Hoverflies. An Illustrated Identification Guide. British Entomological and Natural History Society, Reading, $469 \mathrm{pp}$.

Tamura K., Stecher G., Peterson D., Filipski A. \& Kumar S. 2013: MEGA6: Molecular evolutionary genetics analysis version 6.0. - Mol. Biol. Evol. 30: 2725-2729.

TofILSKI A. 2004: DrawWing, a program for numerical description of insect wings. - J. Insect Sci. 4: 17, 5 pp.

Tomkins J.L. \& MoczeK A.P. 2009: Patterns of threshold evolution in polyphenic insects under different developmental models. - Evolution 63: 459-468.

Tomkins J.L., Котіано J.S. \& LeBas N.R. 2005: Matters of scale: positive allometry and the evolution of male dimorphisms. Am. Nat. 165: 389-402.

То́тн S. 2011: Hoverfly fauna of Hungary (Diptera: Syrphidae). - E-Acta Nat. Pannonica (Supl.) 1: 5-408.

Vekemans X., Beauwens T., Lemaire M. \& Roldán-Ruiz I. 2002: Data from amplified fragment length polymorphism (AFLP) markers show indication of size homoplasy and of a relationship between degree of homoplasy and fragment size. - Mol. Ecol. 11: 139-151.

Vos P., Hogers R., Bleeker M., Reijans M., Van De Lee T., Hornes M., FriJters A., Pot J., Peleman J., Kuiper M., et Al. 1995: AFLP: a new technique for DNA fingerprinting. - Nucl. Acids Res. 23: 4407-4414.

Vujić A., StÅhls G., AČanski J., Bartsch H., Bygebjerg R. \& Stefanović A. 2013: Systematics of Pipizini and taxonomy of European Pipiza Fallén: molecular and morphological evidence (Diptera, Syrphidae). - Zool. Scr. 42: 288-305.

Whitlock R., Hipperson H., Mannarelli M., Butlin R.K. \& BURKE T. 2008: An objective, rapid and reproducible method for scoring AFLP peak-height data that minimizes genotyping error. - Mol. Ecol. Resour. 8: 725-735.

Whitworth T.L., Dawson R.D., Magalon H. \& Baudry E. 2007: DNA barcoding cannot reliably identify species of the blowfly genus Protocalliphora (Diptera: Calliphoridae). - Proc. Biol. Sci. 274: 1731-1739.

Williams K. \& Villet M.H. 2013: Ancient and modern hybridization between Lucilia sericata and L. cuprina (Diptera: Calliphoridae). — Eur. J. Entomol. 110: 187-196. Published online September 15, 2016 